\title{
GÉZA ZICHY A PREŠPOROK
}

\author{
BRANKO LADIČ
}

Katedra muzikológie, Filozofická fakulta Univerzity Komenského v Bratislave

\begin{abstract}
Abstrakt: Štúdia je venovaná grófovi Gézovi Zichymu (1849 - 1924), poprednej osobnosti uhorského kultúrneho života, prvému profesionálnemu lavorukému klaviristovi v dejinách, skladatel’ovi, dirigentovi, ale i básnikovi a spisovatelovi, dlhoročnému riaditel'ovi budapeštianskeho konzervatória a intendantovi Král'ovskej opery v Budapešti, a v neposlednom rade významnému mecenášovi umenia a filantropovi. Ako klavirista dosiahol svetovú slávu, ako skladatel' prispel k vývoju uhorskej opery a k dotváraniu typicky uhorského idiómu v národnej hudbe, i ked’ táto vývojová línia sa na sklonku jeho života vzhl'adom na jej romantické štýlové východiská už javila ako anachronická. Hoci predovšetkým jeho pôsobenie ako interpreta výrazne prerástlo uhorské pomery, celoživotne ostal spätý s Prešporkom - s mestom, v ktorom strávil čast̆ mladosti i štúdiá a neskôr v ňom pôsobil v rôznych oblastiach kultúrneho a spoločenského života. Predkladaná štúdia je koncipovaná ako východisko k d’alšiemu výskumu (štúdium korešpondencie, pozostalostí atd'), ktorý by prispel k prehíbeniu vedomostí o kultúrnom živote Prešporka v skúmanom období.
\end{abstract}

Klúčové slová: Géza Zichy, Prešporok (Pressburg - Pozsony - Bratislava), Franz Liszt, klavírna tvorba, operná tvorba, koncertný život

Géza Zichy (1849 - 1924) patril k popredným osobnostiam umeleckého a spoločenského života Uhorska i celého stredoeurópskeho priestoru poslednej tretiny 19. a prvých rokov 20. storočia. Ako aristokrat bol súčastou spoločenskej elity Uhorska i celej monarchie, ako jednoruký klavirista vzbudzoval obdiv na domácich aj európskych pódiách (popri Rakúsku-Uhorsku koncertoval v Nemecku, Francúzsku, Švajčiarsku, Holandsku, Taliansku, Dánsku, Švédsku, Nórsku a Rusku). Postupne sa presadzoval aj ako dirigent a skladatel' - od menších foriem (piesne, klavírne skladby pre lavú ruku a úpravy diel iných autorov, ktoré komponoval pre vlastné potreby z dôvodu nedostatku repertoáru) prešiel až k orchestrálnej a opernej tvorbe (v rokoch 1896 - 1912 napísal pät opier), pričom vo svojej tvorbe ostal verný štýlovým východiskám romantizmu, ktoré formovali jeho pedagógovia Robert Volkmann a Franz Liszt. Viac než pätdesiat rokov bol Zichyho osud spätý s Prešporkom: žil tu od začiatku šest’desiatych rokov 19. storočia, v roku 1866 tu po prvý raz verejne koncertoval a napriek tomu, že sa začiatkom sedemdesiatych rokov prestahoval do Budapešti ${ }^{1}$, ostal súčast’ou prešporského kultúrneho a spoločenského života až do konca prvej svetovej vojny.

\footnotetext{
${ }^{1} \mathrm{~V}$ prípade magnátskych rodov, ku ktorým Zichyovci patrili, však tažko hovorit’ o jednom bydlisku. Aj Géza Zichy trávil čast’ roka v Budapešti a čast’ v Prešporku, leto spravidla na svojom statku v Tetétlene.
} 


\section{Aristokrat rodom i duchom ${ }^{2}$}

Gróf Géza Zichy sa narodil 22. 7. 1849 v kaštieli v obci Staré (mad'. Sztára) v Zemplínskej župe (dnes okres Michalovce), ako posledný zo štyroch synov grófa Leopolda Zichyho (Zichy Lipót, 1805 - 1869), člena významnej a bohato rozvetvenej uhorskej šlachtickej rodiny, pochádzajúceho z vedrödskej, teda voderadskej vetvy rodu. Stariansky kaštiel' bol majetkom rodiny jeho matky, grófky Márie Sztáray (1821 - 1891). Matkin brat Viktor (1823 - 1879) bol otcom grófky Irmy Sztáray (1863 - 1940), známej ako posledná dvorná dáma cisárovnej a královnej Alžbety Bavorskej. V sztárayovskom príbuzenstve Gézu Zichyho nájdeme aj d’alšiu zaujímavú osobnost', grófa Michala Sztáraya (Sztáray Mihály, 1749 - 1798). Mladší brat starého otca Zichyho matky patril k významným uhorským osvietencom a v aristokratických kruhoch bol známy ako vynikajúci huslista, čembalista a skladatel', z jeho tvorby sa zachovalo niekol'ko polonéz v tzv. galantnom štýle. ${ }^{3}$ Hudobné nadanie teda Géza Zichy zdedil pravdepodobne po matke (sama bola zručnou klaviristkou), nakol'ko o rodine otca hovorí vo svojich pamätiach ako o „naskrze nemuzikálnej rodine “4.

Leopold Zichy sa napriek dôstojníckej hodnosti v rakúskej armáde a dvorskej funkcii zapojil do uhorskej revolúcie na strane Lajosa Kossutha a po porážke revolúcie neunikol perzekúcii. Rodina bola nútená prest’ahovat’ sa do Trnavy (1851), kde žila pod dozorom úradov. Letné mesiace trávili v Smoleniciach (mad’. Szomolány), kam sa Géza Zichy sporadicky vracal aj v dospelosti. Práve v Trnave sa začal zoznamovat’ s klavírom, a to už vo veku troch rokov, prvého učitel’a dostal ako pätročný, od siedmich rokov hral aj na husle. V súvislosti s uvol'nením politických pomerov a po smrti Gézovho starého otca Františka (Zichy Ferenc, 1774 - 1861) sa rodina prestłahovala do Prešporka, pričom letné mesiace trávila v rodinnom kaštieli v obci Seregélyes vo Fejérskej župe. Práve tu došlo 24. 9. 1863 k udalosti, ktorá zásadne zmenila Zichyho život. Pri neopatrnej manipulácii s puškou na polovačke utrpel zranenie, pre ktoré mu museli amputovat pravú ruku. Ťažký úraz s trvalými následkami však mladého muža nezlomil. Prvý list napísaný l’avou rukou adresoval svojmu vychovávatel'ovi Michaelovi von Csiky: „Ked’ odo dneška o rok nebudem schopný urobit’ jednou rukou všetko to, čo iní robia oboma rukami, strelím si gul'ku do hlavy!"

Po niekol'komesačnej rekonvalescencii bol Zichy schopný vrátit’ sa k štúdiu. Vyštudoval Král'ovské katolícke gymnázium a Právnickú akadémiu v Prešporku, a čo je dôležité, vrátil sa aj k hudbe (študoval u Karla Mayrbergera, 1828 - 1881) a ku klavírnej hre. Práve v Prešporku sa 25. 3. 1866 po prvý raz prezentoval verejnosti, a to cyklom mad’arských l'udových piesní upravených pre lavú ruku. Úspech bol jednoznačný a už roku 1867 vystúpil v Budapešti. Po smrti otca (1869) a ukončení prešporských štúdií (1870) sa Zichy prest’ahoval do Budapešti, kde krátko pôso-

\footnotetext{
2 [Bez autora]. "Aristokrat von Geburt und des Geistes", „Wohltätigkeitskonzert". In Westungarischer Grenzbote, 1899, roč. 28, č. 9137, s. 2, 18. 4. 1899.

${ }^{3}$ Pozri PETNEKI, Anna. Mihály Sztáray, ein ungarischer Komponist in der zweiten Hälfte des 18. Jahrhunderts. In Studia Musicologica Academiae Scientiarum Hungaricae, 1/4, Akadémiai Kiadó, 1977, s. 349 - 424. Ide o kompletné vydanie Sztárayovej pozostalosti a muzikologickú štúdiu.

${ }^{4}$ ZICHY, G. Aus meinem Leben I. Stuttgart : Deutsche Verlags-Anstalt, 1911, s. 26. Preklad citátov z nemeckého jazyka B. L.

${ }^{5}$ ZICHY, G. Aus meinem Leben I., s. 82.
} 
bil na ministerstve školstva. V roku 1871 sa oženil s grófkou Melanie Karátsonyi (1855 - 1894), z tohto štastného manželstva sa narodilo pät detí. Zároveň pokračoval v štúdiu hudby, najprv u Roberta Volkmanna (1815 - 1883) a neskôr u Franza Liszta (1811 - 1886), ktorý Zichyho zásadne ovplyvnil a podporoval v jeho interpretačných i skladatel'ských ambíciách. Liszt bol nadšený predovšetkým Zichyho baladou Zach Klára (1873) a jeho úpravou piesne Erlkönig od Franza Schuberta pre l'avú ruku (druhá menovaná skladba bola neskôr zaradená do cyklu Šest' etúd pre l'avú ruku, 1878).

Roku 1875 sa Zichy stal riaditel’om budapeštianskeho konzervatória, túto funkciu zastával až do roku 1918. Prelom v jeho klavírnej kariére znamenal koncert v Paríži (1877) a nasledujúce koncerty vo Viedni a v Nemecku. V osemdesiatych rokoch koncertoval aj vo Švajčiarsku, Taliansku, Škandinávii a Rusku, vždy s vel'kým úspechom. Hrával predovšetkým vlastné skladby, prípadne úpravy známych skladieb od Chopina, Lizsta či Bacha. Popritom d’alej komponoval, popri menších klavírnych a orchestrálnych skladbách napísal napríklad opus Egy vár története ([Príbeh jedného hradu], 1888) - 12 charakteristických kusov pre orchester spojených veršami, akýsi zvláštny útvar na pomedzí suity a melodrámy. Tendencia $\mathrm{k}$ hudobno-dramatickej kompozícii neskôr vyvrcholila v opernej tvorbe.

V januári 1891 bol Géza Zichy menovaný intendantom Král'ovskej opery v Budapešti, a to ako prvý intendant s hudobným vzdelaním v dejinách inštitúcie (táto pozícia patrila k tradičným dvorským funkciám). Jeho pôsobenie vstúpilo do histórie v dost' negatívnom zmysle, a to pre spor s hudobným riaditel'om Gustavom Mahlerom, v dôsledku ktorého Mahler rezignoval na funkciu. Okolnosti konfliktu plnili stránky dobovej tlače v celej monarchii a dodnes sa im venujú mnohí historici a Mahlerovi životopisci. Zichy, ktorého tlač vinila z nekompetentnosti, Mahlerove dirigentské kvality ani v najmenšom nespochybňoval ${ }^{6}$, no nechcel strpiet jeho problematické správanie sa voči ansámblu ${ }^{7}$. Na druhej strane, Mahler sa s budapeštianskymi pomermi nezžil (post zastával od októbra 1888 do marca 1891) a svoje postavenie, aj $\mathrm{v}$ súvislosti s chystanou zmenou intendanta, pravdepodobne pocitoval ako neudržatelné. Už pred nástupom Zichyho jednal s riaditel'om hamburskej opery Bernhardom Pollinim o možnostiach angažmánu (dva listy z 11. 10. a 14. 10. 1890) ${ }^{8}$. Do funkcie hudobného riaditel’a Zichy neskôr získal významnú dirigentskú osobnost', Arthura Nikischa (1855 - 1922), ktorý ako rodák z Mosonszentmiklósa bol napriek nemeckému pôvodu i vzdelaniu považovaný za umelca domáceho pôvodu (vo funkcii 1893 - 1895). Zichyho intendatúru charakterizuje snaha o podporu domácej tvorby i konsolidácia pomerov v divadle - vnútorný poriadok, ktorý vstúpil do platnosti pri jeho nástupe, zostal v platnosti prakticky až do druhej svetovej vojny. ${ }^{9}$ Časovo náročnej funkcie sa Zichy vzdal po náhlej smrti manželky Melanie (zomrela na záškrt 11. 4. 1894), aby sa mohol venovat’ ich detom a umeleckej činnosti. Po smrti syna Aladára

${ }^{6}, \mathrm{~V}$ prvom rade to bol vel'ký človek a každý hudobník cítil, že sa v ňom prejavuje velká muzikantská duša." ZICHY, G. Aus meinem Leben III. Stuttgart : Deutsche Verlags- Anstalt, 1920, s. 167.

${ }^{7}$,Jeho nervózne, príkre, často dokonca nespôsobné správanie privádzalo zavše personál do zúfalstva." Tamže.

${ }^{8}$ NÉMETH, A. Gustav Mahler életének kronikája. Budapest : Zenemükiadó, 1984, s. 118. Autor podrobne líči udalosti, pričom voči Zichymu je vel'mi kritický.

${ }^{9}$ PUKÁNSZKYNÉ KADÁR, J. A Nemzeti Színház Százéves Története II. Budapest : Magyar Történelmi Társulat, 1938, s. 362. 
v novembri 1894 sa rozhodol opustit’ na istý čas Budapešt’ a odíst’ do Prešporka - „do toho mesta, kde som bol kedysi taký štastný “10.

V nasledujúcom období sa Zichy venoval predovšetkým opernej tvorbe. Roku 1896 bola v Budapešti uvedená prvá z jeho opier, Alár. Libreto na námet z uhorského stredoveku spracoval skladatel' sám, podla vlastnej epickej básne z roku 1883. Nasledovala opera Roland mester ([Majster Roland], Budapešt', 1899), opät’ na vlastný námet i libreto. V tomto prípade ide o príbeh zo súčasného života, k čomu autora zjavne inšpirovali úspechy talianskych veristických opier. Nasledujúce tri opery tvoria monumentálnu rákociovskú trilógiu - Nemo (2. diel, Budapešt', 1905), II. Rákóczy Ferencz ${ }^{11}$ (1. diel, Budapešt', 1909) a Rodostó (3. diel, Budapešt', 1912). Vo svojich operných opusoch (s výnimkou opery Roland mester) sa Zichy snažil kreovat uhorskú národnú hudbu - samozrejme, na romantickom základe, avšak s výrazným použitím uhorskej idiomatiky a harmonických i rytmických zvláštností uhorskej l’udovej hudby. Diela zaznamenali výrazný pozitívny ohlas na domácich javiskách (ktorý sa však neukázal ako trvalý) a úspešne ich uviedli aj v cudzine, prevažne v Nemecku.

Géza Zichy sa celoživotne venoval aj literárnej činnosti, písal v mad’arčine i v nemčine. Je autorom lyrickej poézie aj veršovaných epických skladieb (popri spomenutom Alárovi napr. A leányvári boszorkány [Bosorka z Leányváru], 1881), románov (Az álom regénye [Román o sne], 1872), náboženských pojednaní i cestopisov (Élmények Skandináviában [Zážitky v Škandinávii], 1887; Három hét Petervárott [Tri týždne v Petrohrade], 1889). Významným zdrojom informácií o prvej polovici jeho života je trojzväzkové dielo Aus meinem Leben ([Z môjho života], Stuttgart, 1911, 1913, 1920). $\mathrm{V}$ rozsiahlej a farbistej autobiografii sa venuje svojim rodinným pomerom a predkom, bezstarostnému detstvu i tragickému incidentu, prekonaniu svojho hendikepu, umeleckej dráhe i vztahu s Franzom Lisztom. Dielo je rozsiahlym opisom života i doby, avšak čiastočnú nedôslednost’ v uvádzaní faktografických údajov je nutné doplnit', najmä štúdiom dobových periodík.

Na začiatku prvej svetovej vojny sa Géza Zichy angažoval v dobročinných organizáciách, prednášal pre zranených vojakov, dokonca vydal knihu Das Buch des Einarmigen [Kniha jednorukého] (1915) s fotografickou prílohou, zameranú na zvládanie každodenných činností pre vojakov po amputácii končatiny. Z dôvodu vyššieho veku i zhoršujúceho sa zdravotného stavu sa Zichy postupne stiahol z umeleckého aj verejného života. Po rozpade monarchie ostal žit’ v Mad’arsku a zomrel 24. 1. 1924 v Budapešti.

\section{Zichy v Prešporku}

Pôsobenie Gézu Zichyho v Prešporku bolo vel’mi rôznorodé a dotklo sa takmer všetkých oblastí kultúrneho a spoločenského života mesta, v ktorom sa intenzívne angažoval. Popri jeho koncertnej činnosti (ako klavirista a neskôr predovšetkým ako dirigent) sa v štúdii zameriavame na recepciu jeho operných, vokálno-inštrumen-

${ }^{10}$ List Johannovi Batkovi z 23. 11. 1894, v ktorom ho Zichy žiada, aby mu v meste zabezpečil prenájom. Pozri TAUBEROVÁ, A. - MARTINKOVÁ, J. B. Johann Nepomuk Batka: Auswahl aus der Korrespondenz. Bratislava : Slovenské národné múzeum, Hudobné múzeum, 1999, s. 171.

${ }^{11} \mathrm{~V}$ autorskom texte sa pri písaní mena Rákóczi Ferenc držíme súčasne platného mad’arského pravopisu, v dobových textoch sa však vyskytuje vo forme Rákóczy Ferencz. 
tálnych a orchestrálnych diel, ked’že na prelome storočí patril medzi úspešne uvádzaných domácich autorov. Zichy takmer počas celého svojho života ostal súčastou prešporskej society, angažoval sa aj vo viacerých mestských kultúrnych spolkoch, do mesta sa pravidelne vracal a od druhej polovice devätdesiatych rokov až do prvej svetovej vojny tu trávil značnú čast' roka. ${ }^{12}$

Zichyho prešporský debut, koncert 25. 3. 1866 v sále Reduty, mal označenie Musikalisch-deklamatorische Akademie (hudobno-deklamatórna akadémia), ako speváci a hráči účinkovali členovia rodín najvýznamnejšej uhorskej aristokracie. Išlo teda o dobročinný koncert nadaných amatérov, na ktorom zaznela žánrovo rozmanitá zmes skladieb (išlo o bežnú dobovú dramaturgickú prax) - fantázie na témy vtedy známych opier, „Bachova“ Ave Maria (išlo pravdepodobne o Gounodovu meditáciu nad Bachovým Prelúdiom $C$ dur z prvého dielu Temperovaného klavíra), duet z Verdiho La traviaty a sextet $\mathrm{z}$ Donizettiho Lucie di Lammermoor, ale aj zbory z opier Mojžiš $v$ Egypte od Gioachina Rossiniho a Hunyady Lászlo od Ferencza Erkela. Zichy podla vlastných slov ${ }^{13}$ hral svoju Fantáziu na uhorské l’udové piesne (v programe označené ako Ungarische Volkslieder) a sonátu, tá však v programe koncertu nefiguruje ${ }^{14}$. Zichyho meno zato nájdeme v zozname interpretov Rossiniho zboru, išlo pravdepodobne o slávnu modlitbu zo záverečného dejstva.

Géza Zichy, ktorý medzitým po svojich budapeštianskych štúdiách dosiahol vel'ké úspechy v Paríži, Viedni a v Nemecku, spoluúčinkoval aj na koncerte Franza Liszta, ktorý sa uskutočnil 3. 4. 1881 v prešporskom Mestskom divadle. Koncert, ktorého výt’ažok bol venovaný na stavbu Hummelovho pomníka v Prešporku, bol nepochybne najvýznamnejšou udalost’ou kultúrneho života mesta tých rokov. Na železničnej stanici vítali Liszta a Zichyho prešporský hlavný župan gróf Štefan Esterházy a meštanosta Moritz Gottl. Podl'a programu koncertu nemal vtedy šest'desiatročný Liszt hrat žiadnu sólovú skladbu: program uvádza štvorručnú Hummelovu Sonátu As dur, ktorú hral so svojím žiakom Aladárom Juhászom, a Rákócziho pochod ako záverečné číslo, ktoré hral trojručne s Gézom Zichym. Avizované tri kratšie skladby, ktoré mal hrat' Zichy (transkripcia Lisztovho A magyarok istene [Boh Mad’arov], vlastné skladby Magyar abránd [Mad’arská fantázia] a Valse a transkripcia Bachovej Ciaccony d mol pre l'avú ruku), napokon vypadli pre jeho drobné zranenie ruky. Čísla nahradil recitáciou troch svojich básní a Liszt s obrovským úspechom zahral Schubertovu Uhorskú fantáziu a vlastnú transkripciu Rossiniho La charité. Zichy teda hral iba záverečné číslo - Rákócziho pochod. ${ }^{15}$ Po koncerte nasledoval banket v hoteli Palugyay za účastí najvýznamnejších predstavitelov šlachty i mestskej honorácie.

Ďalším Zichyho vystúpením v Prešporku bol koncert 19.1. 1887, ktorého výtažok bol venovaný sirotincu Uhorského kultúrneho spolku. Zichy, ktorý medzitým dosiahol svetovú slávu, hral s vel'kým úspechom svoje skladby: Sonátu G dur, Fantáziu na Mozartovho Dona Juana, Uhorskú fantáziu a ako prídavok vlastnú transkripciu Rákócziho pochodu. Na koncerte odznel ešte Zichyho piesňový cyklus Künstlerfahrt v podaní

\footnotetext{
${ }^{12} \mathrm{~K}$ problematike hudobného života Prešporka (Bratislavy) pozri napr. LENGOVÁ, J. Bratislava ako hudobný fenomén v poslednej tretine 19. storočia. In Musicologica Slovaca, 2010, roč. 1(27), č. 2, s. 183 - 219.

${ }^{13}$ ZICHY, G. Aus meinem Leben I., s. 96.

${ }^{14}$ [Bez autora]. „Programm...“ In Pressburger Zeitung, 1866, roč. 102, č. 69, s. 3, 23. 3. 1866.

${ }^{15}$ J.B. [Johann Batka]. „Das Liszt-Zichy-Konzert für das Pressburger Hummel-Denkmal“. In Pressburger Zeitung, 1881, roč. 117, č. 69, s. 3, 4. 4. 1881. Na koncerte spoluúčinkovali aj speváčky Fanny Kováts a Irene Schlemmer-Ambros a Pressburger Liedertafel pod vedením zbormajstra F. Kitzingera.
} 
tenoristu Richarda Concelliho, známy huslista Karl Hofmeister zahral Zichyho Uhorskú huslovú fantáziu pre husle a klavír a Concerto militaire od Karola Józefa Lipińského, pričom oboch umelcov na klavíri sprevádzal dómsky kapelník Josef Thiard-Laforest. ${ }^{16}$ Hned' na druhý deň, 20. 1. 1887, vystúpil Géza Zichy v Trnave na dobročinnom koncerte v prospech trnavskej filiálky Prešporského kultúrneho spolku, na koncerte spoluúčinkovala grófka Pauline Pálffy ako speváčka a školský inšpektor Josef von Roth ako spevák a violončelista. ${ }^{17}$

V roku 1890 sa Zichy predstavil v Prešporku po prvý raz ako skladatel' rozsiahleho vokálno-inštrumentálneho diela a zároveň ako dirigent. 30. novembra bola v rámci dobročinného koncertu v prospech miestneho speváckeho spolku uvedená kantáta Dolores. Dielo koncipované vo wagnerovsko-lisztovskom duchu vzniklo v roku 1888 a v krátkom čase s úspechom zaznelo v Berlíne, Drážd’anoch, Lipsku i Viedni. Na prešporskom uvedení účinkovali speváčky Fanny Kováts (Dolores), Helene Falkenstein (Sestra predstavená), tenorista budapeštianskej opery Károly Szirovatka (Fernando), zbormajster speváckeho spolku Antal Strehlen stvárnil aj postavu Pustovníka, pod Zichyho taktovkou spoluúčinkovali orchestrálni hráči Mestského divadla. Úspech koncertu bol vel'ký. Podl'a recenzií zaujali kvality diela, dramatický cit skladatela, narábanie s hlasmi a inštrumentácia, aj vynikajúci sólisti, ktorí kvalitou „predčili aj budapeštianske uvedenie diela“18. Recenzent Westungarischer Grenzbote priamo odporúčal Zichymu napísat’ operu. ${ }^{19}$ Tento koncert, konaný v predvečer 25 . výročia Zichyho umeleckej činnosti, bol zároveň príležitostou pre ocenenie umelca zo strany mesta i jeho jednotlivých kultúrnych inštitúcií. Na stuhe venca od mesta bolo uvedené venovanie „dem weltberühmten geistigen Sohne“ („svetoznámemu duchovnému synovi“), v prestávke grófovi gratulovala arcivojvodkyňa Isabella (1856 - 1931), manželka arcivojvodu Friedricha (1856 - 1936) z tešínskej vetvy habsburského rodu, velitel'a miestnej vojenskej posádky. ${ }^{20}$

Arcivojvoda Friedrich kúpil Grassalkovichov palác, v ktorom sa rodina často zdržiavala aj po jeho odvelení do Viedne, vlastne až do konca prvej svetovej vojny. Stály pobyt členov panovníckej rodiny nepochybne zvyšoval prestíž mesta, ktorého prívlastok „korunovačné“ sa v tom čase definitívne vytrácalo zo živej pamäte. K životu arcivojvodského páru patrilo množstvo spoločenských povinností (patronáty najrôznejších podujatí, výstav, dobročinných spolkov atd'.). Kým arcivojvoda sa venoval predovšetkým armáde, priemyslu a pol’nohospodárstvu, arcivojvodkyňa sa realizovala na poli kultúry. ${ }^{21} \mathrm{Tu}$ našla v druhej polovici devätdesiatych rokov spolupracovníka práve v grófovi Zichym, ktorý napokon tiež prispieval k imperiálnemu lesku mesta. Na svojich koncertných cestách sa stretol - iste aj vd’aka svojmu pôvodu - s európskymi korunovanými hlavami i politickými špičkami, napríklad

\footnotetext{
${ }^{16}$ J.B. [Johann Batka]. „Konzert Géza Zichy“. In Pressburger Zeitung, 1887, roč. 124, č. 19, s. 4, 20. 1. 1887.

${ }^{17}$ [Bez autora]. „Dilettantenvorstellung und Konzert zu Gunsten der Tyrnauer Filiale des Pressburger ung. Kulturvereines“. In Westungarischer Grenzbote, 1887, roč. 16, č. 4827, s. 4, 15. 1. 1887.

${ }_{18}$ J.B. [Johann Batka]. Stiftungskonzert des Singsvereines. Zichy-Feier. In Pressburger Zeitung, 1890, roč. 127, č. 310, s. 3, 1. 12. 1890.

${ }^{19}$ [Bez autora]. „Dolores“. Lyrische Dichtung von Graf Géza Zichy, In Westungarischer Grenzbote, 1890, roč. 19 , č. 6198 , s. 1, 2. 12. 1890.

${ }^{20}$ Arcivojvoda Friedrich bol jedným z najbohatších l’udí v monarchii. V rokoch 1882 - 1905 pôsobil ako velitel’ armádneho zboru dislokovaného v Prešporku, v tom čase tu žila i jeho rodina.

${ }^{21}$ Viac k pôsobeniu arcivojvodského páru pozri HOLEC, R. Bratislavskí Habsburgovci. Bratislava : Marenčin PT, 2019.
} 
s nemeckými cisármi Wilhelmom I. a Wilhelmom II., dánskym králom Kristiánom IX., švédskym a nórskym král’om Oskarom II., talianskou král'ovnou Margheritou i ruským cárom Alexandrom III. V spolupráci s arcivojvodkyňou Isabellou sa Géza Zichy podiel'al ako dirigent na viacerých dobročinných koncertoch, často označovaných ako Monstre-koncerty, za účasti mnohých prešporských umelcov a umeleckých zoskupení, ale i prestížnych hostí.

Jeden z Monstre-koncertov sa konal 26. 2. 1896 v Mestskom divadle. V podaní viacerých prešporských umeleckých spolkov, profesionálnych hudobníkov, oboch vojenských kapiel a niekol'kých aristokratických diletantov odzneli výlučne diela Gézu Zichyho. V úvode koncertu zaznel výber zo suity $A$ vár története, pričom básne predniesla grófka Bertha Dessewffy, potom zazneli úryvky z čerstvo dokončenej opery Alár - Ave Mária (Fanny Kováts) a lúbostný duet (sopranistka Kováts a tenorista Szabó). V tom čase sa práve pripravovala svetová premiéra diela v Budapešti (konala sa v marci 1896), dva mesiace po nej nasledovala nemecká premiéra v Karlsruhe. V závere koncertu zaznela Zichyho kantáta $A$ zene [Hudba], ktorú napísal v roku 1895 pri príležitosti 50. výročia budapeštianskeho konzervatória. Zichy vzdal v diele symbolický hold hudbe, ktorá sprevádza človeka od narodenia po smrt’. V živých obrazoch (v tom čase obzvlášt oblúbený typ produkcie), znázorňujúcich jednotlivé časti zo suity $A$ vár története, spoluúčinkovali členovia miestnych šlachtických rodín. Podl’a dobového ohlasu v tlači zabrali prítomní členovia rodiny arcivojvodu Friedricha až tri lóže. ${ }^{22}$

Podobným podujatím pod záštitou arcivojvodkyne Isabelly, avšak ešte väčšieho významu, bol koncert v Mestskom divadle dňa 16. 5. 1897. Usporiadali ho pri príležitosti odhalenia sochy Márie Terézie (autor János Fadrusz) v Prešporku, celodenných osláv i koncertu sa zúčastnil aj panovník František Jozef I. ${ }^{23}$ Základom dramaturgie boli oblúbené živé obrazy, ktoré znázorňovali šest’ významných udalostí z dejín Prešporka, od rozlúčky sv. Alžbety v roku 1211 po Uhorský snem v roku 1741. Každý obraz sprevádzala hudba a predchádzal mu recitovaný prológ napísaný Zichym, ktorý koncert aj dirigoval. Medzi obrazmi odzneli skladby Wolfganga Amadea Mozarta, Richarda Wagnera, Giuseppe Verdiho i diela uhorských autorov (Franz Liszt, Géza Zichy, Jenö Hubay, David Popper, Adolf Szikla). Ako interpreti sa predstavili poprední uhorskí umelci svetového mena - Jenő Hubay, David Popper (hrali vlastné skladby), basista David Ney a sopranistka Szilágyi-Bárdossy i domáca Fanny Kováts. ${ }^{24}$ Úspech predstavenia (hralo sa trikrát) aj výnos pre miestne dobročinné organizácie bol obrovský, lesk podujatia pripomenul prešporské korunovácie.

Dobročinný koncert v Mestskom divadle, opät pod patronátom arcivojvodkyne Isabelly, dirigoval Zichy aj 17. 4. 1899. Program bol zostavený z populárnych kratších skladieb (Robert Schumann, Luigi Boccherini, Carlo Alfredo Piatti, Robert Volkmann) a z piesní a operných árií (Charles Gounod, Almicare Ponchielli, Géza Zichy). Účinkovali hostia z budapeštianskej král'ovskej opery - koncertný majster budapeštianskej opery A. Bürger a speváčka Margit Kaczér, ako aj domáca sopranistka Fanny Kováts. ${ }^{25}$

\footnotetext{
${ }^{22}$ [Bez autora]. „Monstre-Konzert“. In Westungarischer Grenzbote, 1896, roč. 25, č. 8039, s. 4- 5, 27. 2. 1896.

${ }^{23}$ Podrobný opis udalostí pozri HOLEC, R. Bratislavskí Habsburgovci, s. 60 - 66.

${ }^{24}$ [Bez autora]. „Fest-Vorstellung zu wohlthätigen Zwecken anlässlich der feierlichen Etnhüllung des Krönungs-Denkmales“. In Pressburger Zeitung, 1896, roč. 135, č. 134, s. 6, 16. 5. 1896.

${ }^{25}$ [Bez autora]. „Wohltätigkeits- Konzert und Vorstellung". In Westungarischer Grenzbote, 1899, roč. 28, č. 9137 , s. $5-6,18.4 .1899$.
} 
Dňa 9. 1. 1901 uviedol Zichy v Budapešti svoj Koncert Es dur pre l’avú ruku a orchester, venovaný arcivojvodkyni Isabelle. Trojčastové dielo vychádzajúce z tradície romantického klavírneho koncertu je zároveň prvým klavírnym koncertom pre lavú ruku v dejinách. Už o tri dni neskôr, 12. januára, zahral Zichy svoj koncert v Prešporku, vo vel'kej sále župného domu. Pôvodne mal vystúpit’ ako dirigent, no prešporský meštanosta Tivadar Brolly vzhl'adom na budapeštiansku premiéru diela Zichyho vyzval, aby svoju novinku uviedol aj na prešporskom koncerte, ktorého výtažok bol venovaný na stavbu pomníkov Liszta a Petőfiho. ${ }^{26}$ Zichy sa teda po dlhšom čase v Prešporku znova predstavil aj ako klavirista. Na koncerte, na ktorom spoluúčinkovali speváčky Kováts a Zsigárdy a kapelník Josef Stritzl s miestnym vojenským orchestrom, zazneli diela Beethovena, Liszta, Zichyho (popri premiérovanom klavírnom koncerte aj niekol'ko piesní), Zsigmonda Burgera a Kálmána Simonffyho. ${ }^{27}$ Dňa 12. 3. 1913 uviedol Zichy v rámci dobročinného koncertu Speváckeho spolku znova svoju kantátu $A$ zene. Ako sólisti vystúpili sopranistka Benyovszky, tenorista Winkler a basista mestského divadla Szende. Č́sla s a capella zborom dirigoval Eugen Kossow. ${ }^{28}$

Symbolická je účast' Zichyho na dobročinnom koncerte mad’arskej literárnej spoločnosti Toldy-kör ${ }^{29}$ 25. 3. 1916. Pôvodne mal iba prednášat’ o svojej ceste do Škandinávie v roku 1888. Po vrelo prijatej prednáške však školský inšpektor Julius von Rajcsányi pripomenul, že práve v tento deň si umelec pripomína pätdesiate výročie svojej umeleckej činnosti a vyzval Zichyho, aby obecenstvu zahral. Ten si napriek skutočnosti, že už roky verejne nevystupoval, sadol za klavír a zahral niekol'ko skladieb Hymnusz, Rákócziho pochod, uhorskú hymnu a jednu z Lisztových rapsódií, čo obecenstvo odmenilo búrlivým aplauzom. Na koncerte spoluúčinkovali mezzosopranistka Viera von Markovics-Derer s klavírnym sprievodom Alexandra Albrechta, huslista Josef Schuster a v závere vystúpil mládežnícky zbor pod vedením Feliciána Moczika.

\section{Recepcia Zichyho javiskových diel v Prešporku}

Je zaujímavé, že Géza Zichy, v prešporských novinách často označovaný ako Dichter- Komponist (básnik-skladatel'), sa na tunajšom javisku predstavil po prvý raz práve ako básnik: 11. 3. 1898 bola v Mestskom divadle úspešne uvedená jeho trojdejstvová činoherná komédia zo súčasného života $A$ tíz parancsolat [Desat' prikázaní]. ${ }^{30}$ Prvou Zichyho operou, ktorá sa hrala v Prešporku, bol Roland mester, premiéra sa konala 4. 1. 1900. Už sme sa zmienili, že tento opus sa vymyká z radu Zichyho operných diel, nakol'ko ako jediný vznikol na súčasný námet. Je nepochybné, že skladatel' sa priamo inšpiroval talianskou veristickou tvorbou, najviac operou Komedianti od Ruggiera Leoncavalla, aj ked’ azda viac dramaturgicky než hudobne - brutalita veristických jednoaktoviek bola Zichymu predsa len cudzia. Roland je čarostrelec v parížskom cirkuse, v závere jeho manželka Yvette i jej sokyňa, povrazolezkyňa Parbleu, umierajú na javisku priamo počas predstavenia, zavraždené titulným hrdinom. Kri-

\footnotetext{
${ }^{26}$ [Bez autora]. „Graf Géza Zichy als Komponist und linkshändiger Klaviervirtuose für das hies. PetőfiMonument und Liszt- Denkmal“. In Westungarischer Grenzbote, 1900, roč. 29, č. 9733, s. 3, 30. 12. 1900.

${ }^{27}$ [Bez autora]. "Zichy hangverseny“. In Nyugatmagyarországi Híradó, 1901, roč. 14, č. 10, s. 2, 12. 1. 1901.

28 J.B. [Johann Batka]. „Zum nächsten Singvereins-Stiftugs- Konzerte“. In Pressburger Zeitung, 1913, roč. 150 , č. 69 , s. $1,11.3 .1913$.

${ }^{29}$ Géza Zichy bol v rokoch 1910 - 1920 jej prezidentom, funkcie sa vzdal zo zdravotných dôvodov.

30 -nd-."A tíz parancsolat". In Nyugatmagyarországi Híradó, 1898, roč. 11, č. 58, s. 1, 12. 3. 1898.
} 
tika ocenila dramaturgickú a technickú stránku diela, inštrumentáciu aj harmonicky bohatý jazyk. Pod vedením režiséra Viktora Dálnokyho a dirigenta Aladára Tombora sa v hlavných postavách predstavili Elemér Pichler (Roland), Malvin Kann (Yvette) a de Ponty (Parbleu) ${ }^{31}$.

Prešporská premiéra opery Zichyho opernej prvotiny Alár, romantickej opery v prológu a troch dejstvách na námet z uhorského stredoveku, sa uskutočnila 29. 12. 1902, a to za prítomnosti arcivojvodkyne Márie Anny, dcéry arcivojvodu Friedricha, a jej manžela Eliasa, vojvodu bourbonsko-parmského, nevlastného brata budúcej cisárovnej Zity. Dielo po všetkých stránkach zodpovedalo požiadavkám rýchlo sa mad’arizujúceho Prešporka ${ }^{32}$ a snahám o kultiváciu mad’arskej národnej opery. ${ }^{33}$

Opera Nemo, s podtitulom Rákóczy Ferencz hegedőse [Huslista Františka Rákociho], bola v Prešporku uvedená 15. 2. 1906. Titulnú rolu huslistu, ktorému sa pripisuje autorstvo Rákócziho pochodu, stvárnil Elemér Pichler, Rákócziho Ándor Sárossy, Kláru Badínyi spievala Szidi Rédey. Operu hudobne naštudoval Dr. Miklós Bródy, režíroval Lehel Odry. Opera je druhým dielom široko koncipovanej rákociovskej trilógie, námetovo teda spracúva jednu z najzávažnejších tém uhorskej histórie. Zichy sa nechal inšpirovat' kuruckými piesňami i samotným Rákócziho pochodom v závere opery, kritiku zaujala aj inštrumentácia a kompozično-technické detaily. ${ }^{34}$

Prvý diel trilógie, opera II. Rákóczy Ferencz, bol v Prešporku uvedený 16. 1. 1914 (v Budapešti roku 1909), a to za prítomnosti arcivojvodkyne Isabelly a jej detí Alice a Albrechta. Obecenstvo ju prijalo s nadšením, uvedenie opery s národnou tematikou sa stalo doslova patriotickou demonštráciou. Kritika označila Zichyho za znalca kuruckej piesne a ocenila jeho zmysel pre dramatickú výstavbu diela, s dôrazom na strhujúce prvé finále, dramatické akcenty $\mathrm{v}$ druhom a lúbostný duet v záverečnom dejstve, označujúc toto dielo za Zichyho najkrajšie. ${ }^{35} \mathrm{~V}$ hlavných úlohách sa predstavili speváci Falusi (Rákóczi), Ferike Pásztor (Sieniawska) a Kerényi (Ilona Zrínyi).

Popri spomenutých najvýznamnejších koncertných vystúpeniach, na ktorých sa priamo zúčastnil ako interpret-klavirista a dirigent, bola Zichyho tvorba v celom sledovanom období prítomná v hudobnom živote mesta, ked’že patril medzi frekventovaných autorov. Najväčšej pozornosti sa tešili jeho piesne, neskôr sa na koncertných pódiách objavovali aj árie a orchestrálna hudba z jeho opier. Ave Maria pre hlas a orchester sa stala súčastou repertoáru Cirkevného hudobného spolku. Velmi časté a oblúbené boli aj Zichyho prednášky o zážitkoch z početných koncertných ciest či na religiózne témy. Ako významná osobnost’ mestského spoločenského života sa angažoval pri výstavbe pomníkov Liszta, Hummela i Petőfiho, bol členom viacerých mestských kultúrnych spolkov (Cirkevný hudobný spolok, Toldy-kör), aj organizačných výborov pri rôznych podujatiach, napríklad pri Monstre-koncertoch v devätdesiatych rokoch, oslavách 700. výročia narodenia sv. Alžbety (1907) alebo storočnice Franza Liszta (1911). Prešporská verejnost’ so záujmom sledovala Zichyho domáce a zahraničné úspechy, o ktorých referovala miestna tlač, ale aj detaily z jeho

\footnotetext{
${ }^{31}$ J.B. [Johann Batka]. „Roland mester“. In Pressburger Zeitung, 1900, roč. 13, č. 4, s. 6, 5. 1. 1900.

${ }^{32} \mathrm{~K}$ problematike prešporského Mestského divadla v tomto období pozri LASLAVÍKOVÁ, J. Mestské divadlo v Prešporku na sklonku 19. storočia : medzi provinciou a metropolou. Bratislava : Hudobné centrum, Historický ústav SAV, 2020.

${ }^{33}$ J.B. [Johann Batka]. „Gala-Vorstellung“. In Pressburger Zeitung, 1902, roč. 139, č. 357, s. 5, 30. 12.1902.

${ }^{34}$ a.k. "Nemo", Oper von Géza Graf Zichy. In Pressburger Zeitung, 1906, roč. 143, č. 45, s. 5, 16. 2.1906.

${ }^{35}$ a.k. „Opern- Premiére: II. Rákóczy Ferencz“. In Pressburger Zeitung, 1914, roč. 151, č. 17, s. 4, 17. 1. 1914.
} 
spoločenského a rodinného života. Zichyho väzby s osobnostami prešporskej kultúrnej elity najlepšie reprezentuje vztah s mestským archivárom Johannom Batkom (1845 - 1917), jeho blízkym priatel'om a podporovatel'om.

\section{GÉZA ZICHY AND PRESSBURG}

\section{Branko LADIČ}

The study is dedicated to count Géza Zichy, leading figure of Hungarian cultural life, the first professional left-handed pianist in history, composer, conductor, and also poet and writer, long-time director of the Budapest Conservatory and stage manager of the Royal Opera in Budapest. As a pianist, he achieved worldwide acclaim, as a composer he contributed to the development of Hungarian opera and to the shaping of the peculiar Hungarian idiom in national music, although towards the end of his life, this development line was understood as anachronistic due to its romantic style points of departure. Although his work as a performer significantly surpassed the Hungarian context, he remained connected to Pressburg all his life - a city in which he spent part of his youth and studies and later worked in various areas of cultural and social life. The presented study is conceived as a starting point to further research (study of his correspondence, literary estates, etc.), which will contribute to deepening the knowledge about the cultural life of Pressburg in the period under review.

Štúdia vznikla v rámci grantu VEGA č. 2/0040/18 Hudobné divadlo v Bratislave od druhej polovice 19. a do prvej polovice 20. storočia. (Osobnosti, inštitúcie, repertoár, reflexia) a bola vypracovaná v rámci projektu APVV-14-0681 Hudba v Bratislave.

\section{LITERATÚRA}

a.k. „Nemo“, Oper von Géza Graf Zichy. In Pressburger Zeitung, 1906, roč. 143, č. 45, s. 5, 16. 2. 1906. a.k. „Opern- Premiére: II. Rákóczy Ferencz“. In Pressburger Zeitung, 1914, roč. 151, č. 17, s. 4, 17. 1. 1914.

[Bez autora]. „Aristokrat von Geburt und des Geistes“, ,WWohltätigkeitskonzert“. In Westungarischer Grenzbote, 1899, roč. 28, č. 9137, s. 2, 18. 4. 1899.

[Bez autora]. „Dilettantenvorstellung und Konzert zu Gunsten der Tyrnauer Filiale des Pressburger ung. Kulturvereines“. In Westungarischer Grenzbote, 1887, roč. 16, č. 4827, s. 4, 15.1. 1887.

[Bez autora]. „Dolores“. Lyrische Dichtung von Graf Géza Zichy, In Westungarischer Grenzbote, 1890, roč. 19, č. 6198, s. 1, 2. 12. 1890.

[Bez autora]. „,Fest-Vorstellung zu wohlthätigen Zwecken anlässlich der feierlichen Etnhüllung des Krönungs-Denkmales“. In Pressburger Zeitung, 1896, roč. 135, č. 134, s. 6, 16. 5. 1896.

[Bez autora]. „Graf Géza Zichy als Komponist und linkshändiger Klaviervirtuose für das hies. Petőfi- Monument und Liszt- Denkmal“. In Westungarischer Grenzbote, 1900, roč. 29, č. 9733, s. 3, 30. 12. 1900.

[Bez autora]. „Monstre-Konzert“. In Westungarischer Grenzbote, 1896, roč. 25, č. 8039, s. 4 - 5, 27. 2. 1896. 
[Bez autora]. „Programm..." In Pressburger Zeitung, 1866, roč. 102, č. 69, s. 3, 23. 3. 1866.

[Bez autora]. „Wohltätigkeits- Konzert und Vorstellung“. In Westungarischer Grenzbote, 1899, roč. 28, č. 9137, s. $5-6,18.4 .1899$.

[Bez autora]. „Zichy hangverseny“. In Nyugatmagyarországi Híradó, 1901, roč. 14, č. 10, s. 2, 12.1. 1901.

BÓNIS, Ferenc. Béla Bartók: Pictures of a life. Budapest : Balassi, 2006. 552 s. ISBN-10: 963506649X, ISBN-13: 978-9635066490.

EDEL, Theodore. Piano Music for one hand. Bloomington : Indiana University Press, 1994. $136 \mathrm{~s}$. ISBN13: 9780253319050.

HOLEC, Roman. Bratislavskí Habsburgovci. Bratislava : Marenčin PT, 2019. 252 s. ISBN 978-80569-0254-7.

J.B. [Johann Batka]. „Das Liszt-Zichy-Konzert für das Pressburger Hummel-Denkmal“. In Pressburger Zeitung, 1881, roč. 117, č. 69, s. 3, 4. 4.1881.

J.B. [Johann Batka]. „Gala-Vorstellung“. In Pressburger Zeitung, 1902, roč. 139, č. 357, s. 5, 30. 12. 1902.

J.B. [Johann Batka]. „Konzert Géza Zichy“. In Pressburger Zeitung, 1887, roč. 124, č. 19, s. 4, 20.1. 1887.

J.B. [Johann Batka]. „Roland mester“. In Pressburger Zeitung, 1900, roč. 13, č. 4, s. 6, 5. 1. 1900.

J.B. [Johann Batka]. Stiftungskonzert des Singsvereines. Zichy-Feier. In Pressburger Zeitung, 1890, roč. 127, č. 310, s. 3, 1. 12. 1890.

J.B. [Johann Batka]. „Zum nächsten Singvereins-Stiftugs- Konzerte“. In Pressburger Zeitung, 1913, roč. 150, č. 69, s. 1, 11. 3. 1913.

LASLAVÍKOVÁ, J. Mestské divadlo v Prešporku na sklonku 19. storočia : medzi provinciou a metropolou. Bratislava : Hudobné centrum, Historický ústav SAV, 2020. 580 s. ISBN 978-80-89427-47-5.

LENGOVÁ, Jana. Bratislava ako hudobný fenomén v poslednej tretine 19. storočia. In Musicologica Slovaca, 2010, roč. 1, č. 2, s. 183 - 219. ISSN 1338-2594.

NÉMETH, Amadé. Gustav Mahler életének kronikája. Budapest : Zenemúkiadó, 1984. 300 s. ISBN 9633305128, ISSN 0547-2326.

PETNEKI, Anna. Mihály Sztáray, ein ungarischer Komponist in der zweiten Hälfte des 18. Jahrhunderts. In Studia Musicologica Academiae Scientiarum Hungaricae, 1/4, Akadémiai Kiadó, 1977, s. 349 - 424. ISSN 00393266

PUKÁNSZKYNÉ KADÁR, Jolán. A Nemzeti Szinház Százéves Története I. Budapest : Magyar Történelmi Társulat, 1938. $581 \mathrm{~s}$.

SCHONBERG, Harold C. The great pianists. (Rev. and updated ed.). New York : Simon \& Schuster. 532 s. ISBN 9780671638375.

TAUBEROVÁ, Alexandra - MARTINKOVÁ, Jarmila B. Johann Nepomuk Batka. Auswahl aus der Korrespondenz. Bratislava : Slovenské národné múzeum, Hudobné múzeum, 1999. 188 s. ISBN 80-8060-043-0.

ZICHY, Géza. Aus meinem Leben I. Stuttgart : Deutsche Verlags-Anstalt, 1911. $171 \mathrm{~s}$.

ZICHY, Géza. Aus meinem Leben II. Stuttgart : Deutsche Verlags-Anstalt, 1913. 150 s.

ZICHY, Géza. Aus meinem Leben III. Stuttgart : Deutsche Verlags-Anstalt, 1920. 177 s.

\author{
Branko Ladič \\ Katedra muzikológie \\ Filozofická fakulta Univerzity Komenského \\ Gondova 2 \\ 81102 Bratislava \\ e-mail: branko.ladic@uniba.sk
}

